\title{
Diversifikasi Usaha Sanggar Seni untuk Meningkatkan Kesejahteraan
}

\author{
Novi Anoegrajekti ${ }^{1}$, Sudartomo Macaryus ${ }^{2}$, Asrumi ${ }^{3}$, Hanni Miladia Maharani $^{4}$ \\ Sastra Indonesia, FIB, Universitas Jember \\ novianoegrajekti.sastra@unej.ac.id \\ PBSI, FKIP Universitas Sarjanawiyata Tamansiswa Yogyakarta \\ sudartomo@ustjogja.ac.id \\ Fakultas Tarbiyah IAIN Jember \\ miladiamail@gmil.com
}

\begin{abstract}
Abstrak
Sanggar seni di Banyuwangi merupakan salah satu lembaga yang secara swakarsa mengembangkan dan mendidik para calon pelaku seni melalui pelatihan yang ditawarkan kepada masyarakat umum. Pengembangan sanggar merupakan salah satu diversifikasi usaha pelaku seni dalam mempertahankan hidup dan sekaligus mengembangkan seni. Pemimpin sanggar hampir semua adalah para pelaku seni. Selanjutnya, untuk mempertahankan kehidupan sanggar, sebagian melakukan diversifikasi usaha yang dilakukan secara mandiri, kerja sama kemitraan, bantuan fasilitas, dan pemberian pelatihan keterampilan. Kegiatan pengabdian ini bertujuan meningkatkan kapasitas sanggar melalui pelatihan keterampilan pembuatan asesori berbahan logam. Kerjasama kemitraan antara LP2M Universitas Jember dengan Sanggar Tari "Sayu Sarinah" ini diselenggarakan untuk memenuhi kebutuhan tamu dan wisatawan yang hadir di Banyuwangi. Penggunaan motif gandrung berpotensi menguatkan kedudukan gandrung sebagai maskot pariwisata Banyuwangi dan menguatkan tari gandrung sebagai salah satu identitas masyarakat yang memiliki latar belakang sejarah sebagai seni perjuangan dan bermetamorfose menjadi seni pergaulan dan akhirnya menjadi seni hiburan. Arah pengembangan ke depan, di masing-masing destinasi wisata dikembangkan motif cenderamata yang sesuai dengan keunggulan masing-masing destinasi, seperti ritual, pantai, alam, budaya, dan tradisi.
\end{abstract}

Kata kunci: asesori, diversifikasi, logam, pelatihan, sanggar seni,

\begin{abstract}
Art studios in Banyuwangi are ones of the organizations that independently develop and train the potential artists through the training that they offer to the public. The development of art studios is the business diversification of the artists to maintain their life while developing the arts. Almost all studios owners are artists. Furthermore, to maintain the studio's existence, some diversify their businesses independently, collaborate in partnerships, assistance in facilities, and provide skills training. The training aims to increase the capacity of the studio in the manufacturing of metal accessories. The partnership between LP2M University of Jember and the "Sayu Sarinah" Dance Studio was organized to meet the needs of guests and tourists who visit at Banyuwangi. The use of the Gandrung motif has the potential to strengthen Gandrung's position as the mascot of Banyuwangi tourism and strengthen the Gandrung dance as one of the people's identities that has a historical background as an art of war and metamorphose into a social art and eventually becomes an art of entertainment. The direction of future development, in each tourist destination souvenir motifs are developed in accordance with the identities of each destination, such as rituals, beaches, nature, culture, and traditions.
\end{abstract}

Keywords: accessories, diversification, metal, training, art studio 


\section{PENDAHULUAN}

Latar belakang sejarah masyarakat Using Banyuwangi yang wilayahnya menjadi target ekspansi kerasaan-kerajaan besar Jawa Kulonan dan Bali memaksa mereka berkreasi untuk dapat mempertahankan hidup dan identitas mereka. Peralihan penguasa dari kerajaan ke kerajaan tersebut menjadikan masyarakat selalu harus beradaptasi dengan tuntutan kebijakan penguasal yang sedang memegang tampuk kepemimpinan (Anoegrajekti, Sariono, \& Immawati, 2019:67).. Semua itu menjadikan masyarakat Using memiliki semangat egaliter yang terbuka terhadap masyarakat dan budaya dari luar.

Saat ini masyarakat Using yang sebagian besar hidup di lingkungan wilayah pertanian dengan lahan pertanian yang subur juga menghadapi tantangan untuk mempertahankan hidup mereka. Mereka hidup berdampingan dengan berbagai etnis lain yang datang, menetap, dan mencari penghidupan di wilayah Kabupaten Banyuwangi. Berbagai etnis yang tinggal di Banyuwangi antara lain Bali, Bugis, Cina, Jawa, Madura, Mandar, Minang, dan Sunda (Macaryus, Anoegrajekti, \& N Nurdiansyah, 2018:382). Masyarakat dari berbagai etnis tersebut berkecimpung dalam berbagai bidang kehidupan dan menempatkannya sebagai mata pencarharian, seperti sebagai buruh perkebunan, guru, nelayan, pedagang, pegawai, dan petani.

Pilihan bidang kehidupan tersebut menjadikan masyarakat Using sebagai penduduk asli Banyuwangi harus hidup berdampingan dan bekerja sama dengan berbagai etnis yang berasal dari luar Banyuwangi. Hingga saat ini, masyarakat Using tetap menunjukkan sikap terbuka dan egaliter terhadap masyarakat yang datang dari luar tersebut (Maslikatin, Ningsih, Anoegrajekti, \& Macaryus, 2015:370; Saputra, 2016:305). Hal tersebut menjadi salah satu modal sosial bagi masyarakat dalam mendukung kebijakan pemerintah Kabupaten Banyuwangi yang menempatkan pariwisata sebagai salah satu sektor unggulan pembangunan. Pariwisata mengandalkan kehadiran wisatawan domestik dan mancanegara.

Bidang pengembangan pariwisata ini telah ditempuh dengan salah satu kebijakannya menempatkan seni tradisi gandrung sebagai maskot pariwisata Banyuwangi (Anoegrajekti, 2016; Anoegrajekti, Sariono, Macaryus, \& Kusumah, 2018). Gandrung pun hingga saat ini terus mengalami pembaruan. Secara historis gandrung pada mulanya sebagai tari perjuangan, bermetamorfose menjadi seni pergaulan, dan selanjutnya menjadi seni hiburan. Oleh karena itu, kebijakan menempatkan gandrung sebagai maskot pariwisata Banyuwangi dilanjutkan dengan kebijakan yang menempatkan gandrung sebagai tari selamat datang di Banyuwangi. Kedua kebijakan tersebut terjadi pada masa pemerintahan Bupati Samsul Hadi.

Kebijakan yang dilakukan oleh Bupati Abdullah Azwar Anas gayung bersambut dengan yang dilakukan oleh Bupati Samsul Hadi dengan menghidupkan fesyen besar berkelas dunia yang disebut Gandrung Sewu. Melalui kebijakan tersebut seni tradisi gandrung makin populer dan dikenal oleh masyarakat dunia.

\section{KAJIAN SENI TRADISI BANYUWANGI}

Seni tradisi gandrung telah menjadi fokus kajian kalangan akademisi, budayawan, dan pemerhati seni tradisi. Berikut beberapa hasil kajian yang telah dilakukan terdahulu. Murgiyanto dan (Munardi, Seblang, \& Dua, 1990), (Wolbers, 1992), (Puspito, 1998), 
(Anoegrajekti, 2006; 2011; 2016), (Novi Anoegrajekti, Sariono, \& Mustamar, 2009), (Anoegrajekti, Setyawan, Saputra, \& Macaryus, 2015), (Anoegrajekti et al., 2018). Seni tradisi khususnya gandrung telah menghasilkan banyak tulisan berupa makalah, artikel jurnal, dan buku ilmiah. Hal tersebut menunjukkan banyaknya minat kalangan akademisi menggali dan mengeksplorasi akar budaya dan seni tradisi gandrung yang hingga saat ini masih terus dihidupi oleh masyarakat pendukungnya serta menjadi sumber inspirasi berbagai produk industri kreatif.

Besarnya perhatian masyarakat terhadap seni tradisi khususnya gandrung tersebut telah menghasilkan lulusan sarjana, master, dan doktor. Raihan dan prestasi peneliti tersebut cenderung tidak berdampak secara signifikan terhadap kesesahteraan para pelaku seni tradisi pada umumnya, termasuk seni tradisi gandrung. Oleh karena itu, para pelaku seni tradisi menentukan pilihan strategi untuk meningkatkan kesejahteraan mereka. Salah satu cara yang ditempuh adalah melakukan ddiversifikasi usaha, seperti mengembangkan pelatihan tari, vokal, dan panjak. Pelaku seni lainnya mengembangkan profesi sebagai perias dan usaha salon kecantikan, berdagang, investasi usaha bersama, dan membuka usaha jasa boga dan homestay.

Berbagai usaha menggapai kesejahteraan tersebut mendapat dukungan dari negara yang menempatkan tahun 2009 sebagai tahun industri kreatif dan dikembangkannya ekonomi kreatif dengan membentuk lebaga nondepartemen di bawah presiden, Badan Ekonomi Kreatif. Lembaga tersebut menangani 16 subsektor industri kreatif yang berpotensi terus dikembangkan oleh masyarakat Indonesia.

\section{METODE}

Rancangan pengembangan usaha kreatif dengan peningkatan keterampilan ini diawali kegiatan pembacaan potensi dan eksistensi seni pertunjukan Banyuwangen serta permasalahan hidup yang dihadapi para pelaku seni. Kegiatan dilanjutkan dengan menggali dan mengumpulkan data-data primer terkait seluk-beluk, kehidupan dan permasalahan sosio-kultural pelaku seni tradisi dan seniman, pandangan mereka tentang kreativitas, dan kontribusi seni pertunjukan bagi kehidupan ekonomi serta permasalahan-permasalahan yang muncul. Berbagai informasi tersebut diperoleh melalui observasi partisipatoris agar dapat mengamati kehidupan para pelaku seni tradisi di Banyuwangi. Selanjutnya, dengan menggunakan perspektif seni pertunjukan dilakukan pembacaan dengan perspektif estetika, kultural, simbolik, potensi, eksistensi, dan permasalahan -ekonomi, sosial, dan politik- yang ada dalam sebuah praktik seni tradisi (Carlson, 1996; Santoro, 2008).

Khusus dalam bidang pengembangan ekonomi kreatif, (Richardson, 2007) menawarkan empat model terkait sistem dan mekanisme industri kreatif. Pertama, model kesejahteraan merupakan jejaring penggerak pada sektor ekonomi, meskipun membutuhkan biaya besar, yang mampu memberikan kontribusi menyeluruh bagi peningkatan kesejahteraan secara positif. Dengan model ini, industri kreatif melibatkan proses produksi komoditas dengan nilai kultural tinggi, namun menghasilkan nilai pasar rendah atau bisa kurang menguntungkan. Oleh karena itu, cara ini memerlukan partisipasi negara. Kedua, model kompetisi mengabaikan nilai kultural dari produk yang dihasilkan industri kreatif karena mereka pada dasarnya hanya "industri" yang membutuhkan kompetisi dan pasarlah yang menentukan baik-buruknya. Segala keuntungan yang bisa meningkatkan kesejahteraan para kreator atau seniman/wati 
diperoleh dari kompetisi pasar. Model ini berpotensi menimbulkan kompetisi dan saling menguasai. Ketiga, model pertumbuhan mengidealisasi relasi ekonomi positif antara pertumbuhan sektor industri kreatif dan sektor ekonomi secara umum. Industri kreatif memperkenalkan ide-ide yang berpengaruh pada sektor-sektor. Dengan demikian, industri kreatif memfasilitasi proses adopsi dan penguatan ide serta teknologi baru di sektor lain. Keempat, model inovasi mengasumsikan industri kreatif mampu memunculkan dan mengoordinasikan perubahan ekonomi berbasis pengetahuan. Industri kreatif memerlukan kontribusi dan koordinasi ide atau teknologi baru, sehingga berpengaruh pada proses perubahan. Hal itu tampak pada hadirnya teknologi internet yang menghadirkan banyak pengembangan model bisnis.

Sebagai contoh, tenaga kreatif yang terlibat dalam proses produksi dan distribusi sekitar 15 orang tenaga tetap, sementara yang freelance Arie Sandi tidak mencatatnya, karena silih berganti datang dan pergi, khususnya yang terlibat dalam aransmen musik. Data tersebut belum yang termasuk jumlah mereka yang bekerja di Aneka Safari Record dan Khatulistiwa Record. Data tersebut menunjukkan bahwa industri kreatif musik di Banyuwangi mempunyai potensi untuk menggerakkan ekonomi kreatif karena mampu menyerap tenaga kerja dan bisa menumbuhkan modal lokal (Anoegrajekti et al., 2009:131), (Anoegrajekti et al., 2015:86).

\section{KESEJAHTERAAN DAN DEVERSIFIKASI USAHA}

Istilah kesejahteraan berasal dari sejahtera yang berasal dari bahasa Sanskerta catera yang berarti 'payung', sedangkan ke-an membentuk nomina yang berarti 'ihwal'. Seseorang yang mengenakan payung akan dapat terhindar dari panas matahari dan hujan. Dengan demikian sejahtera berarti kehidupan yang terhindar dari berbagai ancaman (Hani'in, 2017:24). Ancaman yang menghadang adalah terbatasnya sumber bantuan dan tidak terbatasnya kebutuhan hidup manusia. Oleh karena itu, usaha yang perlu dilakukan untuk meraih kesejahteraan adalah meningkatkan jumlah dan kualitas sumber bantuan dan menekan jumlah kebutuhan.

Pengembangan sumber bantuan tersebut memerlukan usaha-usaha kreatif, yaitu usaha berbasis kreativitas dan intelektual manusia sebagai pelaku seni dan sekaligus sebagai pelaku usaha. Peningkatan kapasitas sanggar melalui pelatihan keterampilan ditempuh dengan harapan-harapan berikut. Pertama, pelatihan menghasilkan tenaga terampil yang selanjutnya menjadi pelaku industri kreatif. Dalam kegiatan pengabdian ini dikhususkan pada pengembangan keterampilan membuat cenderamata berbahan logam. Kedua, sanggar sebagai inisiator dan mitra memfasilitasi modal, bahan, dan pemasan produk yang dihasilkan oleh para pelaku industri kreatif. Melalui cara tersebut terjadi kerjasama saling menguntungkan dan saling menguatkan. Ketiga, ke depan melalui perjalanan pengembangan industri kreatif berbahan logam berpotensi menjadi media antara pengembangan industri kreatif yang lain. Analisis kebutuhan dilakukan secara langsung melalui harapan dan permintaan konsumen pada umumnya dan para tamu yang hadir di sanggar dan yang menjalin relasi dengan sanggar pada khususnya.

Diversifikasi usaha sebagai langkah peningkatan kesejahteraan telah dilakukan oleh sanggar dan para pelaku seni tradisi. Secara normatif sanggar seni di lingkungan wilayah Kabupaten Banyuwangi harus melakukan registrasi agar terdaftar di Dinas Kebudayaan dan Pariwisata. Syarat normatif ini memungkinkan mereka mendapatkan fasilitas, subsidi dari Pemerintah Kabupaten Banyuwangi, dan menjadi duta dalam 
berbagai festival seni pada tingkat nasional dan internasional. Persyarakat standar tersebut menjadi tahapan awal kehadiran negara untuk memproteksi sanggar seni dan pelaku seni tradisi di Banyuwangi. Hal itu sejalan dengan semangat Bupati Banyuwangi Abdullah Azwar Anas yang dalam beberapa kali pidato menyampaikan bahwa Banyuwangi boleh maju dan berkembang akan tetapi budaya dan tradisi Banyuwangi tidak boleh diabaikan.

Budaya dan tradisi dalam praksis sosial merupakan modal budaya untuk pengembangan pariwisata. Hal itu menggejala pada munculnya paket-paket wisata budaya di Banyuwangi yang dikelola oleh masyarakat dan sanggar seni sebagai realisasi gerakan diversifikasi usaha untuk meningkatkan kesejahteraan para pelaku seni tradisi. Keragaman minat wisatawan memerlukan respons dan antisipasi. Saat ini wisatawan memiliki kecenderungan hadir untuk menikmati destinasi wisata alam, budaya, dan buatan. Oleh karena itu, ketiganya perlu mendapat penanganan secara maksimal.

\section{DARI MASKOT PARIWISATA KE INDUSTRI KREATIF}

Gandrung sebagai maskot parisiwata Banyuwangi dan tari jejer gandrung sebagai tari ucapan selamat datang di Banyuwangi ditetapkan dengan surat keputusan Bupati Banyuwangi Samsul Hadi. Kebijakan tersebut terus diikuti dengan kebijakan-kebijakan lanjutan. Kebijakan lanjutan yang dimaksudkan adalah pelatihan gandrung profesional dan fesyen besar festival gandrung sewu. Pelatihan gandrung profesional diselenggarakan dan dikoordinasi oleh pemerintah Kabupaten Banyuwangi dan ditangani langsung oleh Dinas Kebudayaan dan Pariwisata. Kebijakan tersebtu telah menghasilkan beberapa gandrung profesional yang saat ini mewarnai belantika gandrung profesional Banyuwangi. Fesyen besar festival gandrung sewu merupakan peristiwa budaya besar yang melibatkan penari gandrung dalam jumlah besar. Festival besar tersebut memiliki dimensi strategis berikut.

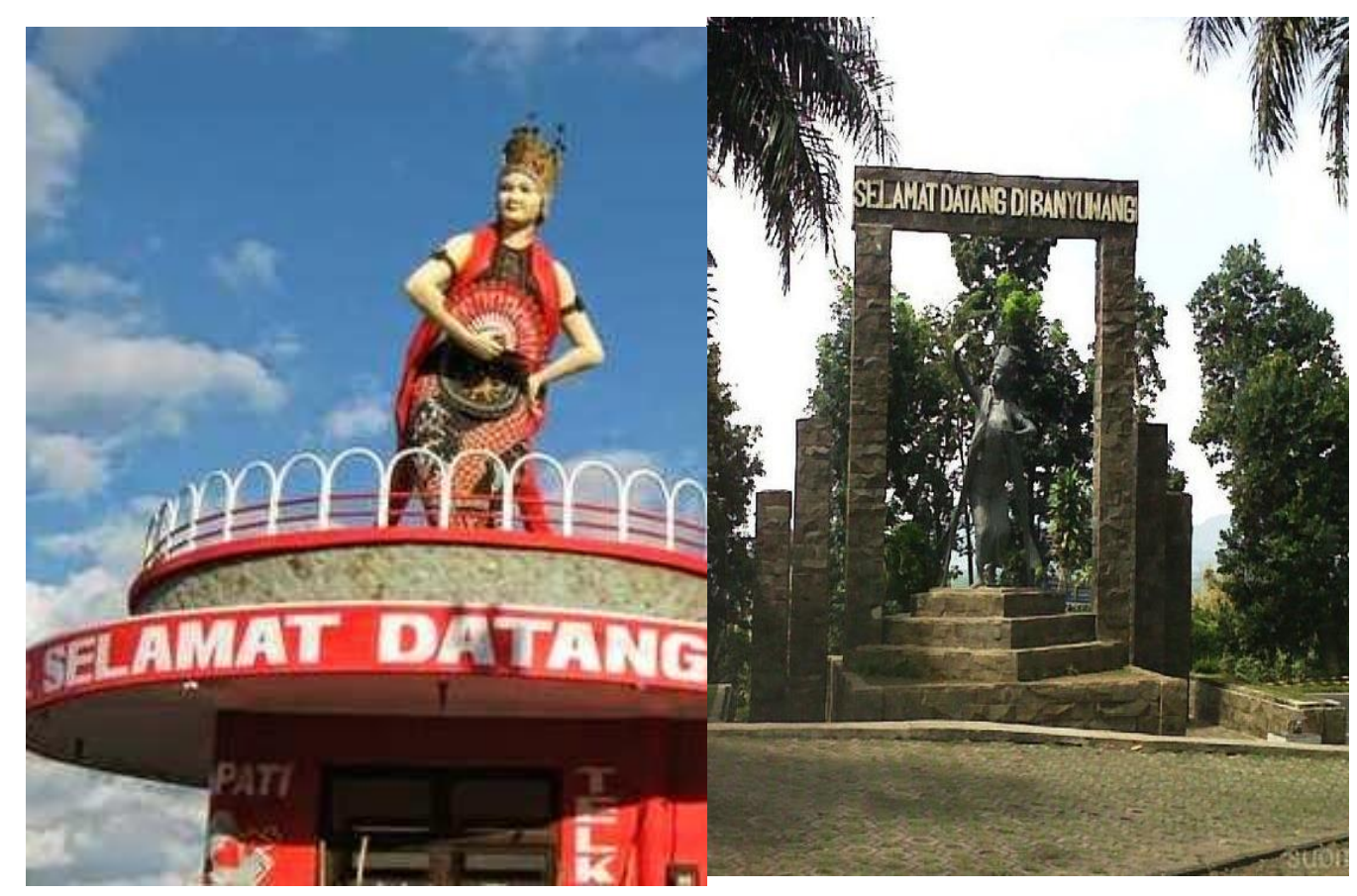


Gambar l: Patung gandrung di Ketapang yang merupakan pintu masuk Banyuwangi melalui jalur laut (Kiri) dan di Gumitir (Kanan) terpasang pintu masuk Banyuwangi melalui jalur darat dari arah Jember (Dokumentasi Tim Periset).

Pertama, memperkenalkan seni tradisi gandrung kepada masyarakat dunia. Kedua, hadirnya tamu yang menyaksikan kegiatan festival gandrung sewu menjadi ruang untuk menyosisialisasikan, mempromosikan, dan memasarkan berbagai produk industri kreatif yang dihasilkan oleh Banyuwangi. Ketiga, fesyen besar tersebut memiliki rantai kegiatan ekonomi yang panjang, mulai dari transportasi, parkir, hotel, kuliner, cenderamata, dan hiburan. Untuk memudahkan tamu dari luar masuk ke Banyuwangi, Bandara Belimbingsari telah memiliki penerbangan langsung dari dan ke Jakarta langsung serta Surabaya-Banyuwangi dan Banyuwangi Surabaya. Keempat, keterlibatan sekolah mulai dari jenjang SD, SMP, dan SMA/SMK menjadi ruang sosialisasi seni tradisi dan pengaderan pelaku seni tradisi yang sistematis. Dengan cara tersebut generasi baru akan terus bermunculan untuk menggatikan generasi yang sebelumnya.

Oleh kalangan akademisi yang melakukan penelitian dengan fokus kajian seni tradisi gandrung diselenggarakan pengembangan motif batik gandrung. Program tersebut dilakukan oleh tim peneliti dari Universitas Jember bekerjasama dengan Dinas Kebudayaan dan Pariwisata serta Dinas perindustrian dan Perdagangan. Pengembangan motif batik gandrung tersebut memiliki beberapa nilai strategis. Pertama, memperkaya koleksi motif batik yang sebelumnya sudah ada di Banyuwangi. Kedua, melengkapi bidang pengembangan industri kreatif yang terinspirasi oleh adanya seni tradisi gandrung. Ketiga, menjadi salah satu alternatif kain (sewek) yang berpotensi untuk digunakan sebagai kostum festival gandrung sewu. Alternatif ini akan menjadi ruang promosi motif batik gandrung kepada masyarakat dunia yang memiliki nilai tambah kepada masyarakat lokal Banyuwangi, mulai dari pengusaha batik, pekerja batik, pencipta motif batik gadrung, dan pedagang batik yang ada di Banyuwangi. Keempat, pengenalan kepada masyarakat dunia tersebut berpotensi menjadikan batik dengan motif yang kelahirannya terinspirasi seni tradisi tersebut menjadi alternatif cenderamata bagi wisatawan dan tamu yang berkunjung ke Banyuwangi.

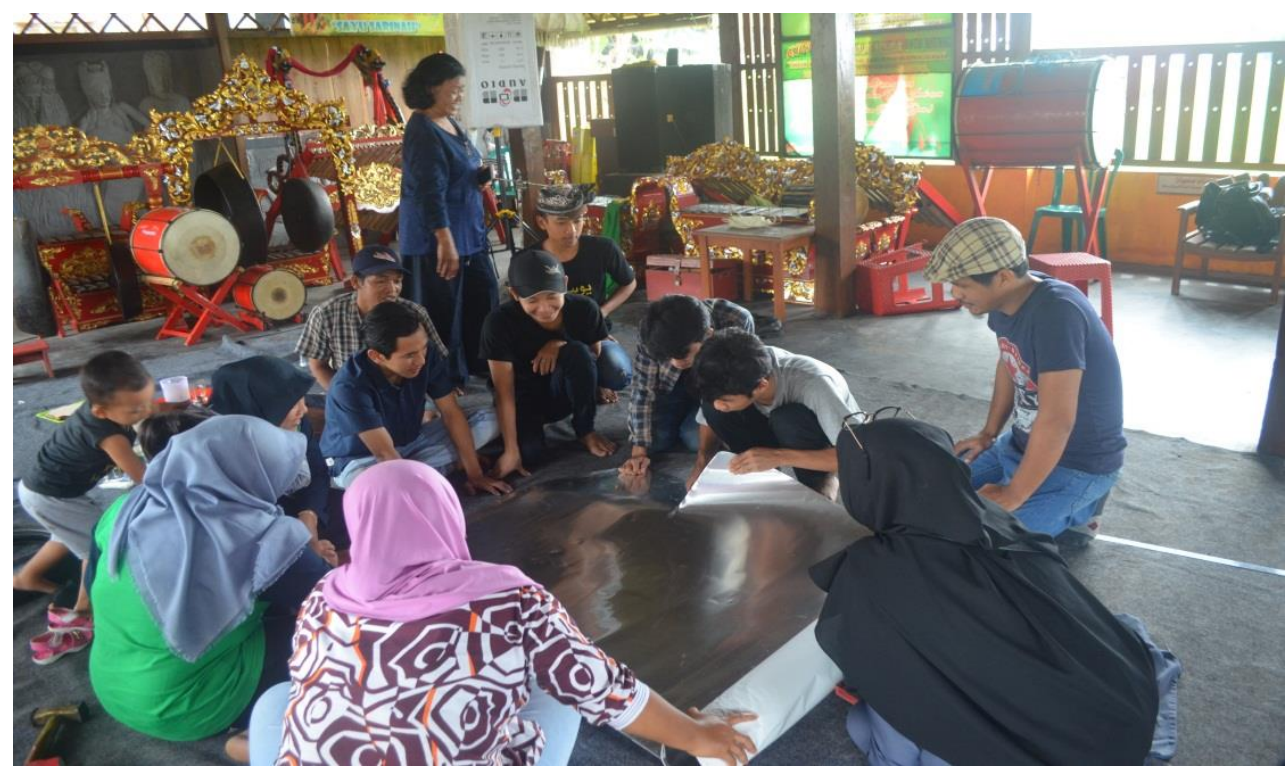


Gambar 2: Sugiyanto (bertopi kotak-kotak), perajin sebagai

fasilitator pelatihan keterampilan pembuatan cenderamata berbahan logam (Dokumentasi Tim Periset)

Akademisi dari Universitas Jember juga pernah mengembangkan keterampilan masyarakat melalui pelatihan keterampilan membuat asesori dan kostum gandrung dan saat ini menyelenggarakan pelatihan pembuatan cenderamata berbahan logam yang diawali dengan motif gandrung. Pelatihan tersebut memiliki beberapa nilai strategis. Pertama, pelatihan pembuatan cenderamata berbahan logam menambah keragaman keterampilan masyarakat yang berpotensi menghasilkan produk untuk mendukung pengembangan pariwisata di Banyuwangi. Kedua, pelatihan ini sebagai respons untuk mengakomodasi kebutuhan masyarakat sebagai pengelola sanggar yang salah satu paket kegiatannya adalah menyediakan penginapan dan ruang transit untuk para wisatawan yang hendak melakukan pendakian ke Gunung Ijen. Dengan demikian persebaran cenderamata ini berpotensi sampai pada tataran global. Ketiga, berdasarkan informasi dari fasilitator, perajin cenderamata berbahan logam yang ada di Banyuwangi masih terbatas. Fasilitator, Pak Yanto sebagai produsen cenderamata berbahan logam kadang mengalami kewalahan melayani permintaan konsumen. Dengan demikian peluang kegiatannya masih luas untuk mengisi dan mencukupi kebutuhan masyarakat. Keempat, pengembangan industri cenderamata berbahan logam dalam skala besar berpotensi membuka lapangan kerja baru untuk masyarakat. Terbukanya lapangan kerja baru tersebut berkontribusi pada pemerintah dan wilayah Kabupaten Banyuwangi dalam meningkatkan produksivitas masyarakat. Kelima, permintaan dan produksi dalam jumlah besar membuka peluang ekspor yang akan meningkatkan pendapatan asli daerah dan meningkatkan devisa negara melalui ekspor produk industri kreatif.

\section{TAHAPAN PELATIHAN}

Rangkaian kegiatan pelatihan dikelompokkan menjadi dua, yaitu prapelatihan dan pelatihan. Kegiatan prapelatihan dimulai dengan rekrutmen peserta diikuti rekrutmen fasilitator dan dilanjutkan dengan diskusi pengorganisasian penyelenggaraan pelatihan. Tiga kegiatan tersebut dikoordinasi oleh mitra pengabdian Sanggar Tari "Sayu Sarinah" yang berdomisili di Desa Olehsari, Kecamatan Glagah, Kabupaten Banyuwangi.

Pelatihan diikuti oleh 10 (sepuluh) orang peserta yang berasal dari lingkungan Kecamatan Glagah dan memiliki semangat kewirausahaan. Fasilitator yang dipilih adalah seorang wirausahawan dan praktisi kriya logam, yaitu Bapak Yanto. Ia sudah menekuni kriya logam dan telah mengikuti pameran di lokal Banyuwangi dan di luar Banyuwangi. Pengembangkan keterampilan untuk masyarakat ini dipandang akan menghasilkan tenaga terampil yang akan menjadi mitra usaha serta memenuhi kebutuhan akan kenangan khas Banyuwangi untuk para wisatawan domestik dan manca negara. Ketersediaan asesori sebagai souvenir khas Banyuwangi ini menjadi kebutuhan untuk mendukung pengembangan pariwisata yang memiliki semboyan sapta pesona. Sapta pesona yang dimaksudkan, yaitu: (1) aman, (2) nyaman, (3) bersih, (4) indah, (5) hijau, (6) tertib, dan (7) kenangan. Setiap wisatawan yang hadir di setiap destinasi wisata di Indonesia pada umumnya dan Banyuwangi pada khususnya diharapkan merasakan dan menikmati ketujuh pesona tersebut. Asesori sebagai cenderamata merupakan pesona yang ketujuh, yaitu kenangan dalam wujud materi yang 
setiap kali dapat dipajang di rumah tempat tinggalnya.

Tahap pelatihan, dilaksanakan berdasarkan hasil musyawarah peserta pelatihan, fasilitator, tim pengabdian, dan Sanggar Tari "Sayu Sarinah" sebagai mitra. Waktu pelatihan diselenggarakan dalam tiga kali tatap muka. Materi pelatihan adalah: (1) pembuatan master motif asesori, (2) pembentukan motif asesori, dan (3) finishing. Susunan materi tersebut merupakan isi pelatihan. Sedangkan urutannya, dalam pelaksanaan pelatihan dimulai dengan materi 2 (dua), yaitu pembentukan motif asesori. Baru, kemudian diikuti materi l (satu) pembuatan master motif asesori dan dilanjutkan dengan materi 3 (tiga), yaitu finishing.

\section{A. Pembentukan Motif Asesori}

Master motif asesori disediakan oleh fasilitaror. Motif awal yang digunakan adalah wajah penari gandrung yang mengenakan omprok, seperti tampak pada gambar berikut. Pada pelatihan pertama ini peserta pelatihan setelah mendapat penjelasan, langsung mempraktikkan penjelasan dengan melakukan pemukulan plat logam di atas master. Semua peserta melakukanpraktik dan hasilnya langsung dapat dilihat bersama. Berikut disampaikan motif mater yang digunakan untuk praktik pembentukan motif asesori, yaitu penari gandrung yang mengenakan omprok.

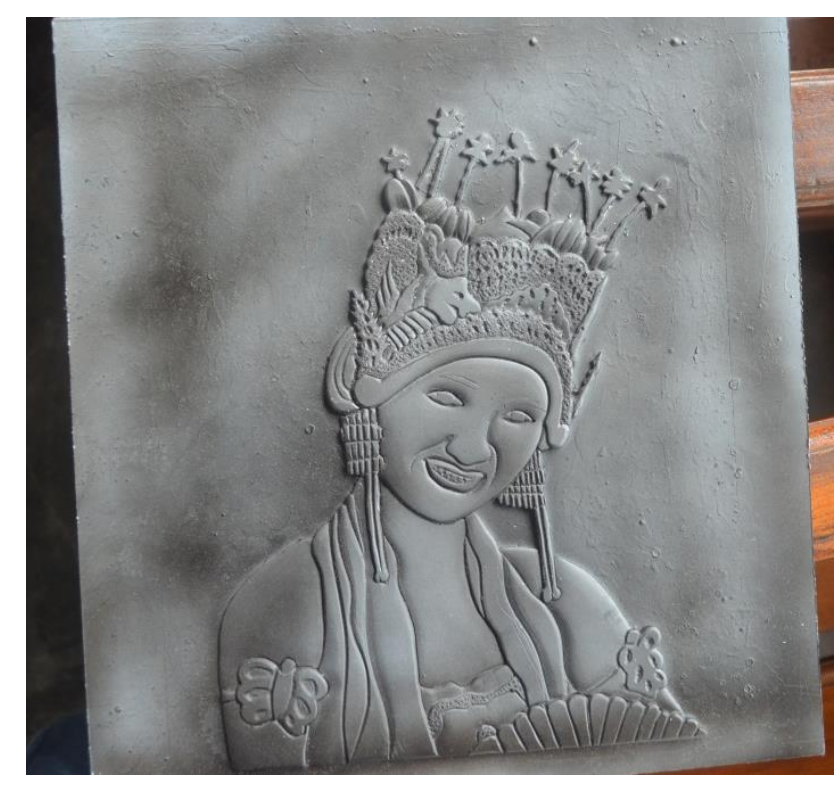

Gambar 3: Master motif gandrung yang terbuat dari paralon (Dokumentasi Tim Pengabdian)

Penentuan materi pembentukan motif asesori tersebut berdasarkan beberapa pertimbangan berikut. (1) Pembentukan motif memberi kesempatan peserta untuk melihat hasil pelatihan secara fisik. (2) Dengan melihat hasil pelatihan secara langsung memberi ruang imajinasi bagi peserta mengenai peran master dalam produksi asesori berbahan logam ini. (3) Pembuatan master motif asesori memerlukan waktu lebih lama dan memerlukan kesabaran. (4) Materi 3 (tiga) baru dapat dilaksanakan setelah ada produk hasil pembentukan motif asesori yang akan diselesaikan. Selain itu materi 3 (tiga) memerlukan alat dan bahan yang pengerjaannya secara bertahap, seperti pengecatan, pembuatan binakai, dan pembingkaian. 
Praktik pembentukan motif asesori dilakukan secara berurutan oleh masingmasing peserta pelatihan. Gambar berikut memperlihatkan saat peserta pelatihan melakukan pembentukan motif asesori dengan melakukan memukul logam yang diletakkan di atas master.
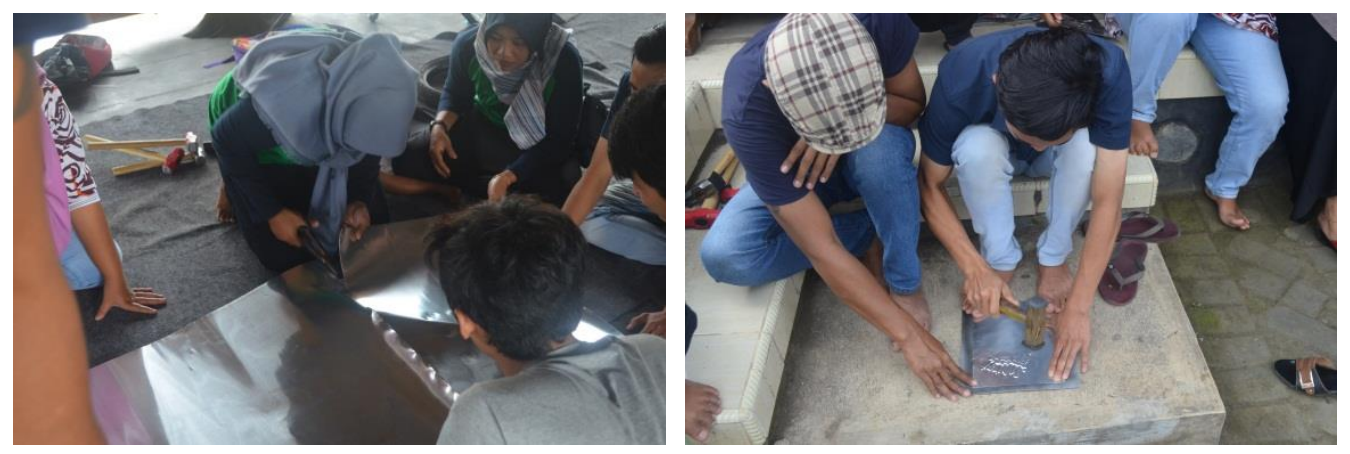

Gambar 4: Praktik memotong logam (Kiri) dan membentuk motif asesori dengan melakukan pemukulan logam yang dibentangkan di atas master (Kanan) (Dokumentasi Tim Pengabdian)

Dalam pembentukan motif asesori ini yang perlu mendapat perhatian adalah penguasaan bagian-bagian yang memerlukan penonjolan garis. Penonjolan garis menjadi penentu kejelasan motif, seperti tampak pada gambar berikut.

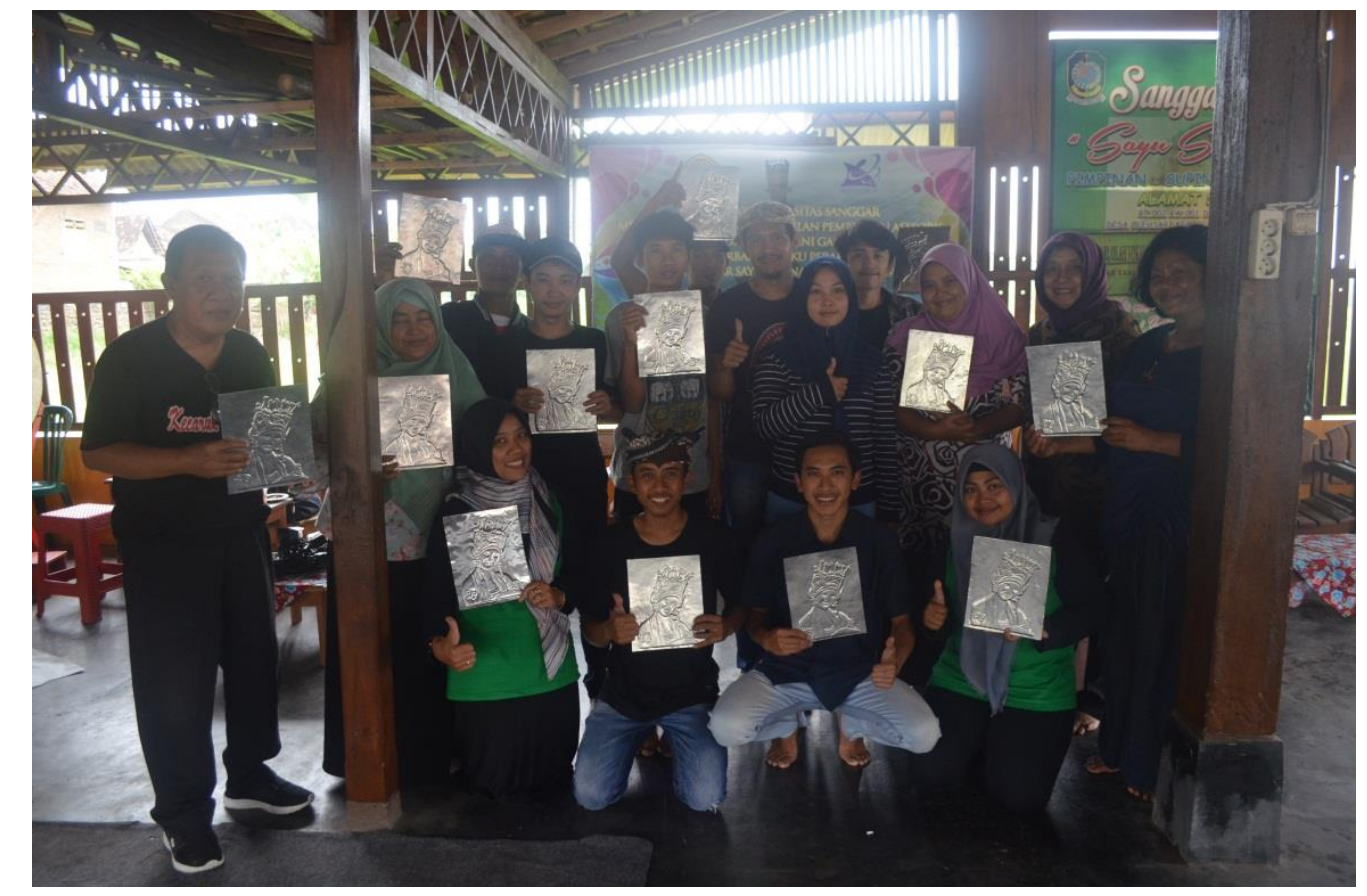

Gambar 5: Hasil pembentukan motif asesori yang dilakukan oleh masing-masing peserta pelatihan (Dokumentasi Tim Pengabdian)

\section{B. Pembuatan Master Asesori}


Pembuatan master dilakukan dengan penjelasan bahan, alat, dan proses. Bahan yang digunakan adalah (1) paralon, (2) lem fox, (3) gambar motif master. Alat yang digunakan adalah kompor, gergaji tripleks, cutter, dan penggaris. Proses pembuatan master adalah sebagai berikut. Paralon dipilih sesuai dengan ukuran yang dikehendaki. Setelah dipotong dan dibelah kemudian dibuat seperti plat dengan cara memanaskan di atas api. Setelah rata, gambar motif ditempelkan di atas plat paralon untuk diporong dengan menggunakan gergaji tripleks. Setelah diperoleh potongan sesuai dengan motif yang dikehendaki kemudian dilakukan pengguratan untuk mendapatkan detail motif seperti yang tercantum dalam gambar.
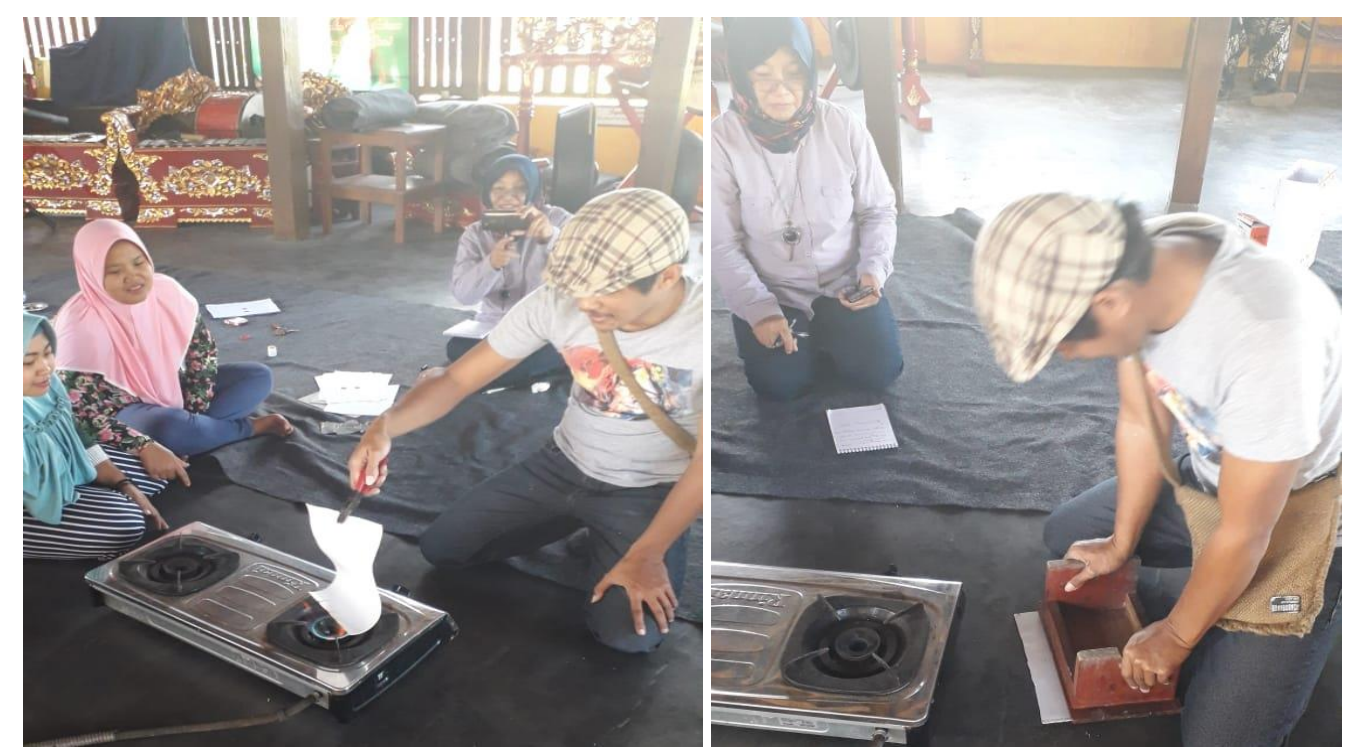

Gambar 6: Paralon dipanaskan di atas api (Kiri) kemudian dipres pada bidang yang datar (Kanan)

Setelah diperoleh paralon yang datar, selanjutnya gambar motif yang diinginkan diletakkan di atas paralon tersebut. Selanjutnya dilakukan pemorongan dengan menggunakan gergaji tripleks, seperti tampak pada gambar berikut.
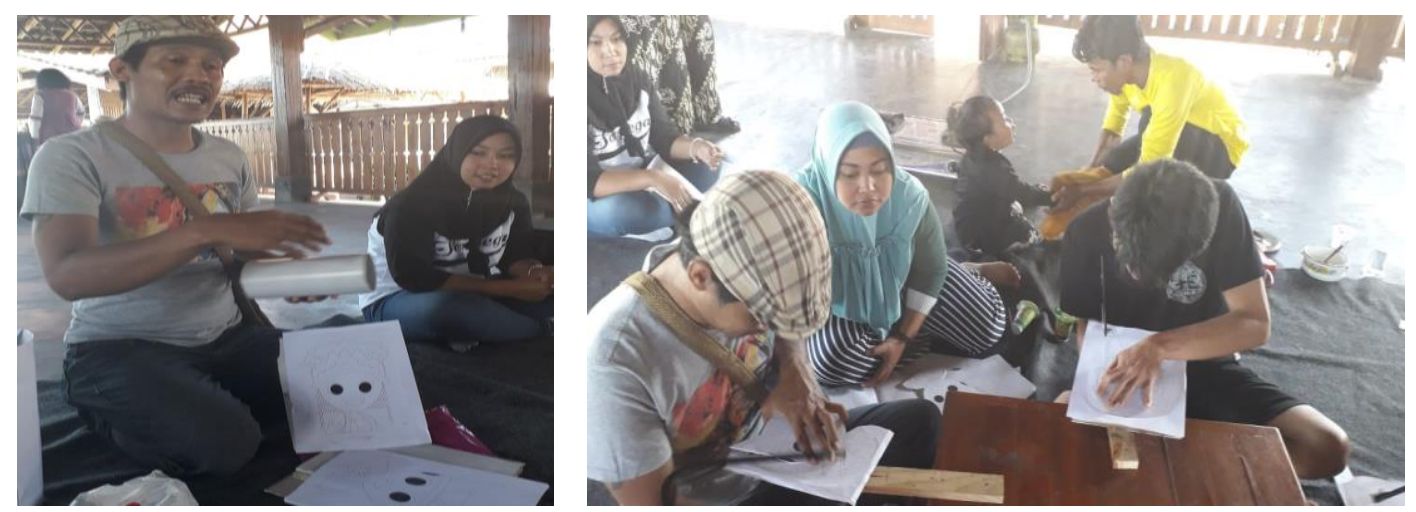

Gambar 7: Gambar motif ditempel pada plat paralon (Kiri) selanjutnya diporong pada garis 


\section{terluar untuk mendapatkan motif dasar (Kanan)}

Seterlah dipetoleh motif dasar, dilanjutkan dengan membuat detail motif dengan melakukan pengguratan untuk mendapatkan detail motif seperti yang ada pada gambar. Pelatihan tahap kedua ini semua sudah mendapatkan motif dasar. Pengguratan detail motif dilakukan di rumah masing-masing setelah mendapat penjelasan dan contoh pengerjaannya. Motif dasar yang sudah dihasilkan tampak pada gambar berikut.

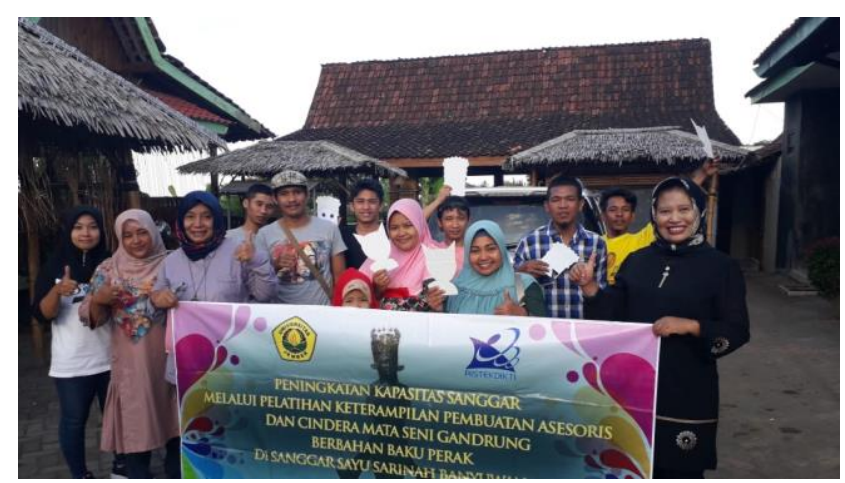

Gambar 8: Peserta pelatihan menunjukkan motif dasar yang telah dibuatnya sedang berfoto bersama fasilitator dan Tim Pengabdian kepada Masyarakat.

\section{KESIMPULAN}

Uraian pada bab-bab terdahulu menunjukkan bahwa deversifikasi usaha berpeluang dilakukan secara mandiri, kerja sama kemitraan, bantuan fasilitas, dan pemberian pelatihan keterampilan. Kerjasama kemitraan antara LP2M Universitas Jember dengan Sanggar Tari "Sayu Sarinah" mengembangkan keterampilan membuat cenderamata berbahan logam diselenggarakan untuk memenuhi kebutuhan tamu dan wisatawan yang hadir di Banyuwangi.

Penggunaan motif gandrung berpotensi menguatkan kedudukan gandrung sebagai maskot pariwisata Banyuwangi dan menguatkan tari gandrung sebagai salah satu identitas masyarakat yang memiliki latar belakang sejarah sebagai seni perjuangan dan bermetamorfose menjadi seni pergaulan dan akhirnya menjadi seni hiburan. Arah pengembangan ke depan, di masing-masing destinasi wisata dikembangkan motif cenderamata yang sesuai dengan keunggulan masing-masing destinasi, seperti ritual, pantai, alam, budaya, dan tradisi.

\section{UCAPAN TERIMA KASIH}

Kegiatan pengabdian ini dibiayai oleh DRPM Kementerian Riset Teknologi dan Pendidikan Tinggi Republik Indonesia melalui Surat Kontrak Nomor 3092/E3.3/PM/2018, tanggal 5 Oktober 2018 dengan Surat Penugasan Nomor: 4388/UN25.3.2/PM/2018, Tanggal 16 Oktober 2018. 


\section{DAFTAR PUSTAKA}

Anoegrajekti, N. (2006). Nyanyian Gandrung: Membaca Lokalitas dalam Keindonesiaan. In Makalah disajikan dalam Seminar Internasional HISKI, Jakarta, 7-10 Agustus 2006. Jakarta, 7-10 Agustus 2006.

Anoegrajekti, N. (2011). Kesenian Using: Resistensi Budaya Komunitas Pinggir. In Kebijakan Kebudayaan di Masa Orde Baru. Jakarta: LIPI-Ford Foundation.

Anoegrajekti, N. (2016). Optimalisasi Seni Pertunjukan: Kontestasi Negara, Pasar, dan Agama. Yogyakarta: Unoversitas Jember bekerja sama dengan Penerbit Ombak.

Anoegrajekti, N., Sariono, A., \& Immawati, E. (2019). Metodologi Penelitian Sastra dan Budaya Karya Sastra dan Pergulatan Budaya. In Teori Kritis dan Metodologi: Dinamika Bahasa, Sastra, dan Budaya (pp. 57-80). Yogyakarta: Program Studi Sastra Indonesia Fakultas Ilmu Budaya Universitas Jember dan HISKI Komisariat Jember bekerjasama dengan Penerbit Kepel Press.

Anoegrajekti, N., Sariono, A., Macaryus, S., \& Kusumah, M. S. (2018). Banyuwangi Ethno Carnival as visualization of tradition: The policy of culture and tradition revitalization through enhancement of innovation and locality-based creative industry. Cogent Arts and Humanities, 5(1), 1-16. https://doi.org/10.1080/23311983.2018.1502913.

Anoegrajekti, N., Setyawan, I., Saputra, H. S. P., \& Macaryus, S. (2015). Perempuan Seni Tradisi Dan Pengembangan Model Industri Kreatif Berbasis Seni Pertunjukan. KARSA: Jurnal Sosial dan Budaya Keislaman, 23(1), 81. https://doi.org/10.19105/karsa.v23il.610.

Carlson, M. (1996). Performance: A Critical Introduction. London: Routledge.

Hani'in, U. (2017). Pengaruh Zakat Produktif terhadap Peningkatan Kesejahteraan Masyarakat Miskin di Kabupaten Sragen. Thesis Institut Agama Islam Negeri Surakarta. Retrieved from http://www.tandfonline.com/doi/abs/10.1080/14639947.2011.564813\%0Ahttp://hei nonline.org/HOL/Page?handle=hein.journals/abaj102\&div=144\&start_page=26\&c ollectio.

Macaryus, S., Anoegrajekti, N., \& Nurdiansyah, Y. (2018). Hibriditas Budaya Jawa: "Praon" Mengiring Gitik di Muncar. In N. Anoegrajekti, H. S. P. Saputra, T. Maslikatin, \& S. Macaryus (Eds.), Sastra dan Perkembangan Media. Yogyakarta: Himpunan Sarjana Kesusasteraan Indonesia (HISKI) Komisariat Jember dan Fakultas Ilmu Budaya Universitas Jember bekerja sama dengan Penerbit Ombak.

Maslikatin, T., Ningsih, S., Anoegrajekti, N., \& Macaryus, S. (2015). Ritual Using dan Jawa: Mitos, Hibriditas Budaya sebagai Integrasi dan Harmoni Sosial. In N. Anoegrajekti, S. Macaryus, E. Boeriswati, F. Murtadho, \& M. K. A. (Eds.), Daya Literasi dan Industri Kreatif: Digitalitas Bahasa, Sastra, Budaya, dan Pembelajarannya (pp. 368-385). Yogyakarta: Jurusan Bahasa dan Sastra Indonesia FBS Unvesitas Negeri Jakarta bekerja sama dengan Penerbit Ombak.

Munardi, M., Seblang, A. M., \& Dua, G. (1990). Seblang dan Gandrung: Dua Bentuk Tari Tradisi 
di Banyuwangi. Jakarta: Pembinaan Media Kebudayaan.

Novi Anoegrajekti, Sariono, A., \& Mustamar, S. (2009). "Kesetaraan Jen-der dalam Perempuan Seni Tradisi." Laporan Penelitian Strategis Nasional DP2M-DIKTI. Jember: Lembaga Penelitian Universitas Jember. Jember: Lembaga Penelitian Universitas Jember.

Puspito, P. (1998). Damarwulan Seni Pertunjukan Rakyat di Kabupaten Banyuwangi di Akhir Abad ke-20. Universitas Gadjah Mada Yogyakarta.

Richardson, D. (2007). Patterned fluidities: (Re)imagining the relationship between gender and sexuality. Sociology, 4l(3), 457-474. https://doi.org/10.1177/0038038507076617.

Santoro, M. (2008). Culture as (And After) production. Cultural Sociology, 2(1), 7-31. https://doi.org/10.1177/1749975507086273.

Saputra, H. S. P. (2016). Welas Asih: Merefleksi Tradisi Sakral, Memproyeksi Budaya Profan. In N. Anoegrajekti (Ed.), Jejak Langkah Perubahan: Dari Using sampai Indonesia (pp. 288-313). Yogyakarta: Pusat Penelitian Budaya Etnik dan Komunitas Lembaga Penelitian Universitas Jember bekerja sama dengan Penerbit Ombak.

Wolbers, P. A. (1992). Maintaning Using Identity Through Musical Performance: Seblang and Gandrung of Banyuwangi, East Java, Indonesia. Urbana: University of Illinois. 